\title{
Lääketieteen filosofisista ongelmista - prof. Tsaregorodtsevin haastattelu
}

T\&E: On suuri kunnia meille saada haastatella Teitä lehteä̆mume varten. Työskentelette filosofian professorina SNTL:n Lääketieteiden Akatemiassa. Mikä asema Lääketieteiden Akatemialla on SNTL:n lääketieteessä ja terveydenhuollossa?

T s a r e g o r od t s e v: Neuvostoliiton Lääketieteiden Akatemia on maan johtava lääketieteen biologisia, kliinisiä ja sosiaalisia perusongelmia tutkiva laitos. Akatemian yhteyteen kuufun 'yli 30 tieteellistä laitosta. Lisäksi sen alaisena toimii filosofian ja vieraiden kielten laitos. Niissä molemmissa harjoitetaan sekä jatkokoulutusta että tieteellistä tutkimustyötä.

T\&E: Suomessa ei ole lääketieteellisissä tiedekunnissa filosofian laitosta. Kërtoisitteko työstänne ja tèhtävistänne?

Ts a r e g or od t s e v: Kaikkien Neuvostoliiton lääketieteellisten instituuttien yhteydessä on myös yhteiskuntatieteiden oppituolit. Opiskelijat perehtyvät marxilais-leniniläiseen filosofiaan kiinteässä yhteydessä oman tieteenalansa kysymyksiin. Lääketieteiden Akatemian filosofian laitos valmentaa aspirantteja filosofian lissensiaatin tutkintoja varten. Filosofian kurssin aikana perehdytään dialektisen ja historiallisen materialismin kysymyksiin ja lisäksi kiinnitétään laajalti huomiota biologian ja lääketieteen filosofisiin ja sosiaalisiin kysymyksiin.

Opetustyönșä ohella laitoksen työntekijät harjoittavat tutkimustyötä. Tutkimustyö tạpahtuu yhteistyössä lääkäreiden ja lääketieteellisten korkeakoulujen sekä tutkimusinstituuttien työntekijöiden kanssa. Julkaisutoimintaan kuuluu lähes 15 monografiaa ja artikkelikokoelmaa sekä lähes 200 lääketieteen ja terveydenhuollon filosofisia ja sosiaalisia $\mathrm{ky}-$ symyksiä käsittelevää artikkelia.

$T \& E$ : Mikä on marxilais-leniniläisen filosofian merkitys lääketieteelle?

T s a r e g o r o d t s e v: Marxilais-leniniläi- nen filosofia on kaikkien tieteiden, myös biologian ja lääketieteen maailmankatsomuksellinen ja metodologinen perusta. Se antaa oikean käsityksen tieteen kehityksen lainmukaisuuksista ja on metodologinen ohje. Luonnonfilosofiasta poiketen se ei tyrkytä konkreettisille tieteenaloille apriorisia kaavoja ja dogmeja vaan katsoo, että on välttämätöntä tutkia faktoja ja tehdä näiden pohjalta yhteenvetoja. Positivismista poiketen se ei sulata problematiikkaansa konkreettisten tieteiden tutkimuspiiriin vaan tutkii konkreettista tieteellistä tietoa filosofian peruskysymyksen kannalta. Marxilais-leniniläisellä filosofialla on myös tärkeä osuus taistelussa porvarillista ideologiaa vastaan, joka nykyään kiinnittää erityistä huomiota lääketieteeseen.

T\&E: Millaisia ovat tärkeimmät lääketièteen filosofiset ongelmat?

T s a r e g o r od t s e v: Lääketieteen ja terveydenhuollon tärkeimpiin filosofisiin ongelmiin lukisin seuraavat: sosiaalisten ja biologisten tekijöiden keskinäissuhde normaalissa ja patologisessa tilassa, fysiologisen ja psyykkisen vuorovaikutus terveydessä ja sairaudessa, määrällisten ja laadullisten muutosten suhde organismin normaaleissa ja patologisissa elintoiminnoissa, diagnostiikka erityisenä tiedostusprosessina, terveys ja sairaus ihmisen elinympäristön ja elinolojen heijastumana, sairauksien muuttuminen ihmisen ja yhteiskunnallisen evoluution seurauksena, terveydenhoito sosiaalisena instituutiona, kapitalismin liiketaloudellisen ja sosialismin humanistisen suhtautumistavan vertailu väestön terveydenhuollossa jne.

T\&E: Miten luonnehtisitte sosiaalisten ja biologisten tekijöiden keskinäissuhteen ongelmaa lääketieteessä?

Ts a r e g o r od t s e v: Sosiaalisten tekijöiden merkitys lääketieteessä ja terveydenhuollossa kasvaa jatkuvasti. Tätä korostavat erityisesti tapahtuneet ekologiset muutokset. 
Erotukseksi eläimistä ihmisen elämäntoiminta ei suuntaudu vain biologisten rakenteiden ja funktioiden säilyttämiseen vaan sillä on sosiaalinen olemus: sosiaalisten funktioiden säilyttäminen eli osallistuminen kollektiiviseen työhön, kollektiivin jäsenten vuorovaitukseen ja luovaan aktiivisuuteen. Ratkaiseva merkitys ihmisen elämäntoiminnan kokonaisuuden kannalta on tuotantovälineillä ja työtoiminnalla. Ihmisen sopeutuminen ympäristön ja työn erityispiirteisiin kussakin uudessa tilanteessa on aina biologisen ja sosiaalisen ristiriitaista ykseyttä. Työ mukauttaa ympäristöä ihmisen biologisiin ominaisuuksiin ja sosiaaliseen olemukseen. Toisaalta ihmisen sopeutumisen perustana ovat lajin- ja yksilökehityksen luomat biologiset mekanismit, joiden muuttumista on toistaiseksi tutkittu vähän. Biologisten toimintojen. muutoksilla on hyvin tärkeä merkitys pyrittäessä työtätekevien työkyvyn säilyttämiseen, työn tuottavuuden kohottamiseen ja terveyden vaalimiseen.

Ihmisen elämä perustuu käsityksemme mukaan kolmelle ryhmällä lainalaisuuksia, joita tutkitaan lääketieteessä. Ensimmäistä ryhmää voidaan kutsua yleisbiologisiksi lainalaisuuksiksi, niille on alistettu kaikkien elävien olentojen elämäntoiminta. Toiseksi on olemassa muuntuneita biologisia lainalaisuuksia, jotka vaikuttavat ilmeisesti ennen kaikkea korkeamman hermotoiminnan välittäminä. Kolmanneksi panemme suurta painoa puhtaasti sosiaalisille lainalaisuuksille, joista riippuu kokonaisten väestöryhmien terveydentila.

Sosiaalisten ja biologisten tekijöiden keskinäinen suhde ei ole samanlainen ihmisen elämäntoiminnan eri tasoilla. Yleisbiologiset lainalaisuudet vaikuttavat puhtaimmillaan molekulaarisella tasolla, soluissa ja pienem- missä yksiköissä. Muuntuneet biologiset lainalaisuudet tulevat esiin elämäntoiminnan korkeammilla tasoilla: elinten, elinjärjestelmien ja koko eliờn toiminnassa. Korkeamman hermotoiminnan säätelemä organismin elämäntoiminnan kokonaisuus on selvimmin alistettu muuntuneille biologisille lainalaisuuksille.

Sosiaalis-biologiset lainaląisuudet muuttuvat ihmisen kehityksen myötä. Otan esimerkin. Aikaisemmin ihmisten fysiologisia ja neuropsykologisia ominaisuuksia muokkasi ennen kaikkea raskas työ, nälkä ja ihmisten suhteellinen eristäytyneisyys. Nykyään ihminen elää laadullisesti erilaisissa olosuhteissa. Etualalla on hermostollinen kuormitus, riittämätön fyysinen toiminta, ihmisten välisten kontaktien voimistuminen ja stressitilanteiden lisääntyminen. On käytetty käsitettä bio-sosiaalinen arytmia. Sosiaalisen ympäristön nopeasti muuttuessa ihmisen biologisten ja hermofysiologisten "prosessien rytmi, tempo ja reaktiot 'jäävät jälkeen tuotannollisesta tahdista ja tuotannon automaation vaatimuksista. Tämä sosiaalisen ja biologisen rytmin epäsuhta onkin epäilemättä yleínen hermostollisten häiriöiden syy ja vakava lääketieteellinen ongelma. Länsimaissa kuitenkin yliarvioidaan bio-sosiaalisen arytnilian mérkitystä sairauksien synnyssä ja unohidetaan työvoiman riiston, tuotannon monopolistisen vă̈äristymisen ja muiden kapitalistisen yhteiskunnan haittaja vaaratekijöiden vaikutus.

Sosiaalisen ja biologisen ongelma on eräs nykylääketieteen tärkeimmistä kysymyksistä, jonka ymmärtämiseliä on suúri teoreettinen ja käytännöllinen méfkitys. Kapitalistisissa maissa on päähuomio kiinnitetty sairauksien biologisen synnyn tutkimiseen ja sosiaalisten tekijöiden selvittely 'on jâänyt Tuhkimon osaan. 